\title{
Beyond Sontag as a reader of Lévi-Strauss: 'anthropologist
}

\section{as hero'}

\author{
By Tod Hartman (University of Cambridge)
}

This article traces mutations in the generalised image of the 'heroic' anthropologist since Susan Sontag's interpretation of the work of Claude Lévi-Strauss in Tristes Tropiques in her 1963 essay, 'The anthropologist as hero'. Firstly, it is argued that a considerable shift has occurred from the Lévi-Straussian 'hard-won impassivity' to 'activist' anthropology in which the anthropologist's emotions are acknowledged and legitimised as part of the ethnographic process. With heroic activist anthropology comes the tendency to assume a single Euro-American vision of rights and responsibilities as universal, although it is suggested that in some contexts this may be in direct conflict with informants' sovereignty and desires. Secondly, as anthropologists increasingly study groups that are located 'at home', the analogy between fieldwork and a heroic journey into the unknown that Sontag posits becomes tenuous. Fieldwork is now carried out in places - the hospital, the airport, the office - that would have been unthinkable several decades ago. In these explicitly de-exoticised contexts in which they are often held accountable to their informants, anthropologists are able to demonstrate a heroic honesty with regards to their subjects of study. Finally, it is suggested that the generalised perception of anthropologists from outside the discipline has not taken these new sorts of heroisms into account, and that this omission has worked to the detriment of anthropology's external image.

\section{Introduction}

In a 1963 essay in The New York Review of Books, 'The anthropologist as hero', the writer and critic Susan Sontag presents American audiences with the work of Claude Lévi-Strauss in the context of his newly-translated book Tristes Tropiques (1961). The condition of the contemporary intellectual for Sontag is a constant and frustrating attempt at a dialectic self-identification with the Other: Europe seeks its self in an exotic Other, a disenchanted rationality seeks itself in the ecstasy of sex and drugs, philosophical problems seek their 'oblivion' in the empiricism of science (Sontag 1994:69). For Sontag, however, only the anthropologist has actually lived this desire to lose the self in the Other through the emotionally cathartic disorientation of fieldwork: the anthropologist is the only practicing intellectual who is master of 'his own intellectual alienation' (ibid:74). In Sontag's reading of the practice of ethnography, which seems uniquely positioned to anticipate the self-reflexive trend in the discipline ushered in by the work of Lévi-Strauss, the emotional trauma of fieldwork is a double one: not only is one constantly and agonisingly forced to call into question the parameters of one's own existence and assumptions by contact with the exotic Other, but one is forced to watch helplessly as indigenous cultures are irrevocably destroyed by the processes of modernisation. 
To a large extent, this may still be how the practice of anthropology is viewed from outside the discipline. Yet, as anthropologists increasingly study groups that are not necessarily 'non-Western' or located abroad, as they study elites or their own societies, or celebrate their intervention into societies under study in the context of activism or development, the traditional analogy between fieldwork and a heroic journey into the unknown and back in some cases becomes tenuous. In this paper I will suggest that a different sort of anthropologist as hero has emerged since the period when Sontag reviewed Tristes Tropiques. This figure continues to embody many of the characteristics of Sontag's anthropologist, yet it also presents new sorts of conundrums as it engages emotionally with notions of anthropology-as-activism and the deterritorialisation of the traditional anthropological dialectical subject (the exotic Other).

Throughout this essay, I take Sontag's text (rather than a literal reading of Lévi-Strauss) as a constant point of comparison. Sontag wrote for a very small audience, a very rarefied slice of Euro-American urban Anglophone elites: the reader she addressed could claim familiarity with the theatre of Ionesco, was versed in French existentialism and could contextualise the literary criticism of Georg Lukács. In addition, her vision of the ethnographic spectrum is sharply divided between the primitive native and the civilised Western anthropologist. From these two facts one might conclude that she has little to tell us now about an egalitarian anthropology, and if, as a cursory reading of 'The anthropologist as hero' suggests, anthropology deserves interest only to the extent that it is practiced and elevated to the level of highbrow philosophy by European intellectual elites, we might do better to disregard the essay entirely.

Yet I rely on Sontag's writing not because it embodies some correct notion of what ethnographic practice should be, but because I consider it representative of the perception of anthropology from outside (and possibly inside) the discipline at a particular moment when self-reflexive anthropologists began to turn an analytical and philosophical gaze back onto themselves and their own emotions - a moment that Sontag, one of the most cross-culturally well-read figures of the twentieth century, was uniquely poised to appreciate and record (although she was by no means the only one to do so). With reference to that moment I will interrogate some forms of the evolution of the anthropologist as hero, an admittedly fuzzy term when taken out of context, but one whose malleability for an author I hope will help to draw out the changes in the ways that anthropologists contextualise their emotional engagement in the field. I draw on several topical ethnographic cases, as well as my own experience of fieldwork in Romania and Spain. Finally, I will suggest that a wider recognition of the anthropological heroisms that Sontag doesn't address might contribute to a revitalised image of the practice of anthropology from outside the discipline.

As an initial observation - and a recognition that pinning the label 'heroic' to different sorts of ethnographic practice is a highly vague, subjective and potentially contentious affair-it is worth remarking that notions of heroic anthropologists inscribe themselves in a historical conception of heroism that is relatively new. For much of history, heroic status is awarded retroactively-that is, after the hero's death. It is the hero's status as martyr that makes him (or more rarely, her) heroic. Joan of Arc's heroic status is derived from the fact of her immolation. 'Unknown soldiers' killed in battle attained the highest level of heroism in many modern nation-states not through specific acts achieved whilst 
alive, but by the single fact of their death. Here, it is their very anonymity that makes the ultimate sacrifice of these soldier-martyrs all the more pointed: not only have they laid down their lives for patriotic duty, but the subjective achievements of their lives have gone unrecorded, unrewarded.

The heroic anthropologist, on the other hand, lives on, in many cases to be fêted as an 'engaged intellectual' by virtue of his or her own status as such. In most cases, during the course of fieldwork, one neither dies nor disappears into one's informants. One is permitted to complete the act of fieldwork - the 'psychological ordeal' (Sontag 1994:75) — but when it finishes its planned duration or becomes unbearable one returns, in most cases, to the comfort of the Western academy, not as a failure but as a hero. One is then expected, in a final and fantastic opposition to the hero-as-martyr above, to record the heroic experience in one's own terms. Compared to the hero-as-martyr, anthropology as heroism cannot but seem like a case of having one's cake and eating it too.

In addition, for Euro-American intellectuals of the 1960s, if Sontag is anything to go by, the heroic practice of anthropology was inherently a masculine one. Anthropology, as Sontag notes, is one of the few intellectual trades that does not require the 'sacrifice of one's manhood' (ibid:74). Throughout her essay the paradigmatic anthropologistdespite the presence of a large number of well-known female anthropologists and especially the advent of Margaret Mead as the icon of the progressive anthropologist in American popular consciousness by the mid-twentieth century-always remains a 'he'. While this observation alone should establish the fact that the heroic anthropologist is a shifting figure with little basis in reality, it is informative to look at the reception of the hyper-masculinised anthropologist at one end of a spectrum of anthropologist as hero as a starting point for the discussion to follow.

\section{Dangerous heroics}

The Monou-teri and Bisaasi-teri raided against the Patanowä-teri six times while I lived with them... I allowed them to talk me into taking the entire raiding party up the Mavaca River in my canoe. There, they could find high ground and reach the Patanowä-teri without having to cross the numerous swamps that lay between the two villages. (Chagnon 1968:134-135)

Not without good reason, the now controversial work of the US anthropologist Napoléon Chagnon is often taken as the instance par excellence of anthropology as adventure. In the 1960s Chagnon conducted extensive fieldwork amongst the Yanomami, a group of Native Americans in the Northwest Amazonian rainforest on the border between Brazil and Venezuela. Out of this fieldwork emerged the classic text Yanomamö: The Fierce People (1968; later changed to simply Yanomamö) in which Chagnon described the Yanomami as an intensely warlike society, whose existence centred around revenge, raids and battles for control of women. Chagnon followed these often fatal large-scale acts of violence over the course of various years, even going to the point of arming natives himself (ibid:13). Reading passages from Yanomamö, one is surprised that Chagnon managed to survive his fieldwork at all. Here, we see the hyper-masculinised anthropologist as hero taken to its natural extreme, as the danger and physical hardship with which the anthropologist's rite de passage in the field is fraught become a barometer 
of his heroism and the real interest of the book, long a core text in introductory cultural anthropology courses at US universities. Would Chagnon's account still contain any of the gripping, riveting power that fuelled its status as a bestseller and classic anthropological text if the field experience had been calm, safe and comfortable, if it failed to depict anthropology as heroic adventure?

A recent book-cum-exposé by journalist Patrick Tierney, Darkness in El Dorado (2001), accuses Chagnon of a variety of sins: falsifying data, encouraging inter-tribal warfare, unduly influencing the course of local politics and feuds, even going so far as to suggest that it was the anthropologist who caused the region's current instability. One of the most significant and divisive scandals in the recent history of sociocultural anthropology, the conflict provoked an extensive report by the American Anthropological Association (AAA Executive Board 2002), which largely exonerated Chagnon from accusations of ethical misconduct. Whether or not Chagnon is in fact guilty of the charges levelled against him is in a sense beside the point. Rather, what emerges as significant are the changes that have occurred in the character of the anthropologist as hero since the middle of the twentieth century. Today, the heroic anthropologist is less often the one who sets out on a heroic mission of self-discovery, hardship and adventure, and more often the self-reflexive anthropologist whose first intellectual impetus is to critique the very idea of doing ethnography as problematic in itself. One of the reasons why Lévi-Strauss was ahead of his time, what makes him the ideal anthropologist and Tristes Tropiques so wellachieved for Sontag, is the fact that he was able to do both these things.

What we see more and more today are anthropologists who practice a kind of responsible ethnography, or anthropologists who frame their projects around notions of a universalist human rights discourse. It is not surprising that in this climate a project such as Chagnon's - which is nothing less than a manifestation of cultural relativism taken to its normal conclusion (one does not oppose but rather goes along with practices that may well lead to the death of one's informants in order to avoid passing moral judgement on them and influencing the society under study) — now becomes susceptible to criticism. The anthropologist as hero begins to define him- or herself in opposition to what Sontag refers to as Lévi-Strauss' 'hard-won impassivity' (1994:72). Rather, a certain type of emotional subjectivity that legitimises itself by appeals to universal notions of responsibility, commitment and engagement is the heroic quality of this new anthropologist as hero, the prime exemplar of which is the anthropologist as activist.

\section{Activism as heroic anthropology}

In a recent article in American Anthropologist, Shannon Speed (2006) argues eloquently for activism in the practice of ethnography. Speed draws on her own research as anthropologist-cum-human rights activist working to secure indigenous identification and territorial rights for Tzeltal Indians in Chiapas, Mexico. She acknowledges the various criticisms that might be levelled at the idea of anthropology-as-activism: it is unduly interventionist, the emotional involvement it implies may be incompatible with maintaining a critical analytical focus, the anthropologist may need to essentialise informants in order to fight legally for a group's rights. Yet the way forward, Speed suggests, is a critically engaged anthropology of rights incorporating overt activism on 
the part of the anthropologist, which addresses head-on the dilemmas listed above, transcending the 'paralysis' in research on human rights brought about by the debate between universalism and relativism (ibid:74). Rather than essentialising one's informants, the heroic activist-anthropologist uses activism to engage with them.

Yet with this move, the ones who do end up as an essentialised group seem to be anthropologists themselves. The last sentence of Speed's article drives home the idea that activist research contributes to the 'ongoing struggle for greater social justice' (ibid:75), which seems to be implicitly taken as some sort of final and all-justifying theoretical point. But this begs the question of whether there really is some sort of blanket notion of social justice that exists within the discipline of anthropology and that can serve as a convincing justification for one's own ethnographic methods. That is, is there any room in this scenario of the engaged activist anthropologist as hero for an anthropologist whose own political views differ from those of the discourse of equality and rights as defined by the Western liberal democracies? What if, for example, we had the rather unlikely scenario of the anthropologist allying herself with local landowners and fighting for the increased appropriation of land from the remaining indigenous communities under the banner of the economic progress of the Mexican state? This may well be engaged, activist anthropology, but it seems unlikely that it would fall into the category of what many anthropologists today would consider 'social justice'. Yet if anthropology is to be truly non-ethnocentric, there is a certain inconsistency in restricting the parameters of what activism might involve to a specific liberal Euro-American vision of social justice.

This year the Royal Anthropological Institute in the UK sponsors a fellowship in Urgent Anthropology, designed to 'facilitate ethnographic research on currently threatened indigenous peoples, cultures and languages' and 'if possible help such peoples in their struggle to survive' (RAI 2006). Is this not the ultimate embodiment of the heroically activist mission of anthropology, an advocacy of rights that seeks to safeguard the most basic human right - the right to exist? And within this heroic activist mission, a logical conclusion is that ethnographically speaking almost any interventionist practice can be rationalised because of its inscription in a crisis situation, in a state of emergency. With the entrance of activism as a legitimate pursuit in the context of fieldwork, the anthropologist as hero goes from being an adventurer, one who undergoes a personal catharsis, to one who effects a change for the good of the society under study; heroic anthropology moves from the personal to the moral. This is a long way from what Sontag refers to as Lévi-Strauss' 'Lucretian pessimism" (1994:73), the primacy of 'hard-won impassivity' (ibid:72) in the practice of ethnography.

This shift raises an important question concerning the workings of the academy. The heroic anthropologist who combines human rights activism and fieldwork seems to become the exemplar of the 'engaged intellectual'. Human rights give the anthropologist a certain moral currency, a (perhaps unfair) advantage over other academics or graduate students who inscribe their research in the 'merely academic' or the 'simply theoretical'. How can the work of such anthropologists ever be challenged, or interrogated by other anthropologists? By other academics? Not only have these heroic activist anthropologists

\footnotetext{
1 Lucretius, the first-century BC Roman philosopher, advocated the study of the sciences and the resignation to the utter randomness of fate as an anecdote to fear and superstition and a consolation for the inevitable fact of death. Lévi-Strauss prefaces Tristes Tropiques with an excerpt from his De rerum natura.
} 
left, for the most part, the easy confines of the Western academy, but they have selflessly risked life and limb to end the mistreatment of an indigenous Other. For these anthropologists, overt emotional involvement is the barometer of their commitment to the discipline, rather than the strict maintenance of the technique de dépaysement (literally, the 'technique of removing oneself from one's country', i.e. self-induced cultural disorientation) as a stance from which to analyse a given culture (Lévi-Strauss 1968:117) — what Sontag refers to as Lévi-Strauss' 'exquisite, aristocratic version of neutrality' (1994:74) - and calling any aspect of their work into question may seem tantamount to a callous sanctioning of whatever abuse or exclusion has been visited on their informants.

For the most part, this activism is done with the best of intentions, and often achieves concrete results, but is it anthropology as we know it? In a detailed if overly empirical analysis of the history of the relationship between anthropology and human rights, Messer (1993) suggests that cultural relativism within anthropology has gradually been eroded since the United Nation's 1948 Universal Declaration of Human Rights, and anthropologists have evolved to the point of now actively contributing to a 'universal ideology' (ibid:240) of human rights. This is a strange position, especially if, as Messer is keen to point out, the very concept of 'universal rights' was regarded by anthropologists from the outset as being ethnocentrically Western (cf. the American Anthropological Association's statement on human rights submitted to the UN Commission on Human Rights, 1947). Following in this tradition, surely it would be more useful also today, especially for anthropologists, to locate the notion of rights in instances of local sociality, or, if a 'democratic' definition is required, from within the Greek polis, which is, before anything else, the proper ancestor of the Euro-American liberal democratic system.

Those who would de-problematise a recourse to universalism in the context of anthropology might do well to remember the central theme of Lévi-Strauss' critique of ethnocentrism, a constant questioning of the 'objectivity and universality of Western history' (Doja 2006:21), and the principle by which he gained his very deserved reputation: there are no superior societies (De Gramont 1974). From this it follows that, even though there may perhaps be one accepted universal definition of rights, there can be no superior definition of rights when, as Messer (1993) illustrates, opposing definitions exist in different states and different regions of the world, and many of them are not based on the Western liberal democratic model.

My own research drove home the problematic nature of taking one definition of rights and responsibilities as universal. My $\mathrm{PhD}$ fieldwork amongst illegal Romanian workers in Spain in 2004-2005 revealed that when faced with the opportunity to register themselves in the context of an official granting of residence permits to illegal migrants, my state-suspicious informants would do anything to avoid being inscribed in the bind of the Western European liberal democratic state with its specific rights and restrictions. The Lévi-Straussian technique de dépaysement, which Kurasawa reads as the 'cross-cultural mode of estrangement of the modern West, from which it could be interpreted and radically put into question' (2004:115), allowed me to think beyond my initial emotional, proto-activist (and quite erroneous) instincts upon arriving in the field-instincts that posited illegal Romanian labourers as exploited agency-less victims of exclusion who naturally desired nothing more than a heroic Western European anthropologist to help 
them through the complicated legal procedures necessary to become 'official', when in fact they knew very well the social restrictions implied in becoming legal subjects and wanted no such thing.

Here, an activist anthropology informed by the liberal democratic doctrine that no one should be subject to a right-less state of exclusion would have been antithetical to informants' sovereignty and desires. Their voluntary alienation from the product of their back-breaking labour - the cheap vegetables that fill the supermarkets of Northern Europe - and their unwillingness to gain legal status or pursue upward economic mobility were not instances of 'resistance' or 'negotiation' with capitalist power structures. Rather, they were a reflection of an ongoing deferral of acceptance of the current capitalist status quo in favour of an undefined 'something better', a shifting 'utopian object of impossible fullness' (Žižek 2000:206) that defied definition in the terms of the former. An anthropology unable to think outside the box of the universalist, Western proto-capitalist liberal discourse on rights and aspirations would have no access to this object, a central core of my informants' subjectivities.

Although at a global level this may well be an unrepresentative example (insofar as illegal Romanian workers in Spain had the luxury of refusing the offer of incorporation into the official economy of a wealthy Western European state, while many other types of migrants in other parts of the world are not offered that sort of choice), it serves to illustrate the problems associated with taking one single definition of rights that one's emotions tell one are just and fair as a universal aspiration for all in ethnographic analysis. As Sillitoe (1998) notes, in the context of anthropology and development, anthropology is in a uniquely privileged position to offer insights into local indigenous knowledge and promote 'bottom-up' participation, countering this tendency towards the positing of a monolithic set of aspirations and needs for the world's poor. Yet, in a discipline that is both inherently subjective and critical, activist anthropology, of which ethnography carried out in the context of economic development is a part, seems to overemphasise the subjective element of anthropological knowledge while under-emphasising the critical.

\section{Heroic anthropology at home and away}

If it is the practice of fieldwork that endows anthropology with the potential to be heroic, surely 'setting off', leaving the home environment and going off into the unknown, is the moment at which that heroic journey begins. Or at least, that may well have been the case when Sontag wrote 'The anthropologist as hero', when any study of the social carried out within Euro-American societies was more often than not subsumed under the label of 'sociology', and when, 'for the anthropologist, the world is professionally divided into "home" and "out there", the domestic and the exotic, the urban academic world and the tropics' (Sontag 1994:74). Today, however, Western-based anthropologists do not always need to leave home to carry out fieldwork or find objects of study. These objects of study are not merely the same traditional subaltern informants transposed into a Western context (refugees, asylum seekers, minority communities, etc.), but social actors whose entire existence may be anchored in the anthropologist's own society (e.g. an ethnography of English village life, an ethnography of an office of civil servants), or 
entities that reveal relational networks between people in a mostly Euro-American context (e.g. ethnographies of biotechnology, ethnographies of bureaucracy, or ethnographies of disease). What is considered especially topical by journals is finding its place more at home: refugee detention camps, borders or the laboratory. And it is in these places that the anthropologist as hero, even the activist anthropologist as hero, is increasingly finding his or her home. We should not, however, assume that a shift in focus away from a distant, subaltern Other implies some final global democratisation of anthropology: just as Euro-American anthropologists no longer need to leave home to carry out fieldwork, many non-Western anthropologists incorporated into the discipline must do exactly that in order to have their status as anthropologists 'legitimised' in terms of acquiring degrees from universities in Western Europe and North America.

It is worth asking what the lack of the cathartic journey to the unknown and the disorientation of the field implies for the new anthropologist as hero at home. This type of ethnography at home is certainly far from Lévi-Strauss and Sontag's notion of the anthropologist as hero (can we contemplate a re-writing of Tristes Tropiques without the element of travel?). Yet, why privilege the ethnographic subject, or even the subaltern ethnographic subject, as being situated somewhere on the other side of a border or across an ocean? Have anthropologists up until now been like London elites, who journey to the exotic poverty of Thailand and Vietnam and send their children on gap years to build homes for the poor in Africa, but would never contemplate setting foot in Camberwell or Elephant and Castle?

It is specifically this lack of geographical displacement on the part of the anthropologist that now comes to constitute a sign of heroic dedication. What better way to demonstrate one's commitment to one's project than to follow it not to the exotic, but to the mundane, to the known? For anthropologists, is not the sacrifice of contact with the exotic Other an indisputable exhibition of one's ethnographic integrity? The practice of anthropology 'at home' means that anthropologists are assumed to be held to a certain standard of accountability - an ethnography in the context of a hospital will most likely be read, critiqued and reacted to by the doctors, nurses and administrators whom it considers. This is a far cry from the illiterate, geographically distant native informants that Sontag considers in 'The anthropologist as hero', who, one might assume, are not sent advance copies of Tristes Tropiques in order to elicit their critical comments. In this sense, conducting anthropology at home has a double heroic function: on the one hand, the ethnographer, seen to be held to standards of accountability, is assumed to be acting at the very highest level of honesty with regards to the representation of his or her informants. Secondly, an ethnography conducted at home is often absolved of any connotations of epistemological imperialism - one cannot simply represent informants in any fashion one wants with total impunity, but rather is seen to be engaging in a two-way process where the construction of knowledge is a collaborative one.

Especially with anthropology done at home, there is the sense that rather than penetrating a static, essentialised culture, it is culture itself that now directs the direction and scope of anthropology: anthropologists position themselves at the heroic vanguard of change by 'responding' to topical new innovations in technology, new modes of consumption, or new patterns and techniques of communication. The vision of the future of this heroic anthropology of the new stands in complete contrast to that of Sontag's heroic 
anthropologist, with his Lucretian pessimism. For Lévi-Strauss, writing in 1955, the tropics are inherently tristes (literally, 'sad') because contact with Europeans has reduced their native inhabitants to a condition in which they are 'miserable, ugly, syphilitic, and almost extinct' (Sontag 1994:73). Sontag's reading of Lévi-Strauss is: 'Anthropology is necrology. "Let's go and study the primitives," say Lévi-Strauss and his pupils, "before they disappear" (ibid). For the new heroic anthropologist, by contrast, the future is not the necrological space of the inevitable demise of culture, but a constantly expanding space of possibility and change that it is one's challenge to try and keep up with-even, in some cases, to overtake.

\section{Conclusion}

Susan Sontag was not an anthropologist, and her vision of the practice of anthropology, informed overwhelmingly by an admiration for mid-twentieth century French structuralism - 'it occupies itself with only the formal features which differentiate one society from another' (1994:78) - may seem overly simplified to us now. However, reading her 'Anthropologist as hero' today, with its sensitive rendering of the anthropologist as a figure beset by doubt, by pessimism, by a constant questioning of his own knowledge and emotions, suggests the extent to which the tradition of Lévi-Strauss did help to usher in the self-reflexive tradition in ethnographic writing.

Yet Sontag is an empathetic rather than an objective critic. Interpreting Lévi-Strauss, she dismisses quite quickly other schools of thought and other anthropologists, for example Malinowski and Radcliffe-Brown, as 'nonsense' (ibid:78). It has certainly not been my intention here to follow Sontag's lead in privileging the emotional catharsis, the technique de dépaysement, and structuralist sensibility of the Lévi-Strauss of the 1950s as the authentic core of anthropology, and to suggest that any divergence from these things constitutes a betrayal. Activism, the deterritorialisation of the traditional informant, and fieldwork without travel are all logical responses to specific historical circumstances and needs. Likewise, different sorts of historically contingent quasi-anthropological heroisms (for example, civilising, colonialist, missionary) occurred long before Lévi-Strauss wrote Tristes Tropiques or the advent of structuralism.

In a recent study of the popular literary image of anthropologists, Jeremy MacClancy (2005:551-555), after an impressive consideration of 170 works of fiction involving anthropologists, juxtaposes the idea of a heroic anthropologist with that of the 'pathetic' anthropologist. The pathetic anthropologist is incapable of normal human interaction and emotion at home and prefers to observe even the intimately social from a position of cool analytical superiority. Here, anthropology and fieldwork become a kind of neurosis, a substitute for a lack of personality or a counterweight to some sexual dysfunction. The motivation for setting out for fieldwork is a negative one: staying away from his or her home society fits in neatly with the pathetic anthropologist's natural position as an outcast and a pariah. This might be contrasted with MacClancy's heroic anthropologist's inspiration for going to the field. The heroic anthropologist, brilliantly talented, has a whole range of intellectual disciplines clamouring to include him or her in their ranks, yet chooses anthropology because 'anthropology meant doing things, not just reading about them' (ibid:555). The heroic anthropologist in MacClancy's literary survey is high- 
minded, sexually attractive and aware (although not irresponsibly so), compassionate, engaged and, in the final analysis, 'boringly predictable' (ibid). It is perhaps no wonder that it is the pathetic anthropologist, not the heroic one, whose presence overwhelmingly dominates the works of (mostly Anglophone) fiction that MacClancy has analysed.

The popular image of the anthropologist, from what one can infer from this literature, remains true, by default at least, to Sontag's vision of Lévi-Straussian fieldwork, to fieldwork as emotion at the personal rather than collective level. The fictional pathetic anthropologists that dominate the literature are incapable of emotional engagement (ibid:551); their gaze is that of the regard lointain (the detached gaze). They must journey to exotic lands to carry out fieldwork rather than remaining at home (ibid:55560 ), and of the 170 works that MacClancy reads, in not a single one does an anthropologist engage in activism (ibid:566). It is not unreasonable to ask, then, whydespite its often lofty goals, heroic activism, and pioneering shifts of focus away from its traditional subject - our discipline is viewed as pathetic? It seems, as De Pina-Cabral writes in the context of the recent proposed axing of funding for anthropology by France's main research body, the CNRS, that 'the public understanding of anthropology is not what it should be' (2006:663, original emphasis).

Here lies the real potential of the shifting, malleable concept of anthropologist as hero: it is time for the rest of the world to be introduced to the new anthropological heroisms, with their different forms, contradictions and emotional complications, and their potential for an external revitalisation of the discipline. Whether or not one agrees with the shift away from relativism implied in anthropology as activism, or finds a less glamorous, less exotic and more familiar subject worthy of ethnographic study, it is clear that anthropology now engages head-on with the world in ways that would have been unthinkable in the 1960s. One hopes Sontag's successor will be writing with this in mind.

\section{References}

American Anthropological Association (AAA) Executive Board. 1947. Statement on human rights submitted to the Commission on Human Rights, United Nations. American Anthropologist 49, 539-543.

- 2002. Final report of the AAA El Dorado Task Force, http://www.aaanet.org/edtf/index.htm.

Chagnon, N. 1968. Yanomamö: The Fierce People. New York: Holt, Rinehart and Winston.

De Gramont, S. 1974 [1968]. There are no superior societies. In Claude Lévi-Strauss: The Anthropologist as Hero (eds.) E.N. Hayes and T. Hayes, 3-21. Cambridge, Mass.: MIT Press.

De Pina-Cabral, J. 2006. 'Anthropology' challenged: notes for a debate. Journal of the Royal Anthropological Institute 12, 663-673.

Doja, A. 2006. The predicament of heroic anthropology. Anthropology Today 22(3), 1822. 
Kurasawa, F. 2004. Ethnological Imagination: Cross-cultural Critique of Modernity. Minneapolis, Minnesota: University of Minnesota Press.

Lévi-Strauss, C. 1961 [1955]. Tristes Tropiques, trans. J. Russell. New York: Criterion.

- 1968 [1952]. The concept of archaism in anthropology. In his Structural Anthropology, trans. C. Jacobson and B. Schoepf, 101-19. Harmondsworth: Penguin.

MacClancy, J. 2005. The literary image of anthropologists. Journal of the Royal Anthropological Institute 11, 549-575.

Messer, E. 1993. Anthropology and human rights. Annual Review of Anthropology 22, 221-249.

Royal Anthropological Institute (RAI). 2006. RAI Fellowship in Urgent Anthropology, http://www.therai.org.uk/rainews/urgent rai announcements.html.

Sillitoe, P. 1998. The development of indigenous knowledge: a new applied anthropology. Current Anthropology 39(2), 223-252.

Sontag, S. 1994 [1963]. The anthropologist as hero. In her Against Interpretation, 69-81. London: Vintage.

Speed, S. 2006. At the crossroads of human rights and anthropology: toward a critically engaged activist research. American Anthropologist 108, 66-76.

Tierney, P. 2001. Darkness in El Dorado: How Scientists and Journalists Devastated the Amazon. London: W.W. Norton \& Co.

Žižek, S. 2000. The Ticklish Subject: The Absent Centre of Political Ontology. London: Verso.

\section{About the author}

Tod Hartman is finishing a PhD in social anthropology at Cambridge. His thesis, entitled The Gift of Cheap Labour, considers Romanian workers in the social space of the illegal labour market in an agricultural region in the south of Spain. This research is based on fieldwork in Transylvania and the greenhouse construction industry in Andalusia. He has also carried out research on consumption and aesthetics (France), consumption and interior design amongst the 'new rich' (Romania), and expressions of utopia in the postsocialist context (Romania). He can be contacted at tgh24@cam.ac.uk 